\title{
Factors Influencing Serum Amyloid Type A (SAA) Concentrations in Horses
}

\author{
Katy Satué $^{1 *}$, Antonio Calvo ${ }^{2}$, Juan Carlos Gardón ${ }^{2}$ \\ ${ }^{1}$ Department of Animal Medicine and Surgery, Faculty of Veterinary, \\ CEU Cardenal Herrera University, Valencia, Spain \\ ${ }^{2}$ Department of Experimental Sciences and Mathematics, Faculty of Veterinary, \\ Catholic University of Valencia, Valencia, Spain \\ Email: ksatue@uch.ceu.es
}

Received January 18, 2013; revised February 18, 2013; accepted March 8, 2013

\begin{abstract}
The acute phase response (APR) is the reaction that occurs in animals in response to disturbances in hemostasis following tissue damage. In horses, the APR is manifested in a variety of pathological processes of various origins, such as infections caused by bacteria, viruses, parasites, arthritis, burns, chemicals, trauma surgery and stress. Acute phase proteins (APPs) are considered those proteins that modify its plasma concentration at least $25 \%$ in inflammatory and infectious processes. In adult horses, various respiratory inflammatory processes, gastrointestinal tract, reproductive organs and musculoskeletal system are accompanied by increased levels of a specific APP, so-called serum amyloid type A (SAA). SAA is the most important major APP in the horse. This paper provides a review of physiological factors affecting SAA levels and their role in horses in defense of natural mechanisms, the pathways involved and their material components.
\end{abstract}

Keywords: Acute Phase Response; Serum Amyloid A; Equine

\section{Introduction}

The acute phase response (APR) is the reaction that occurs in animals in response to disturbances in hemostasis following tissue damage [1,2]. The main functions of this systemic response are to provide energy and substrates for the fight against invading pathogens, preventing the transfer of metabolites necessary to pathogens, limiting the damage caused by pathogens and/or remove damaged or infected tissue and restore it. During the development of APR release pro-inflammatory cytokines interleukin-1 (IL-1), interleukin-6 (IL-6) and tumor necrosis factor (TNF- $\alpha$ ) that act through different receptors on the membrane of hepatocytes, certain proteins synthesized in the so-called acute phase proteins (APPs), including: C-reactive protein, serum amyloid A (SAA), haptoglobin, fibrinogen, $\mathrm{C}$-reactive protein, ceruloplasmin and $\alpha_{1}$-acid glycoprotein [1-4].

SAA is the major protein in horses and presents the following characteristics: they are present at very low or undetectable levels in the serum of healthy animals but increase rapidly from 10 to 1000 times during the APR. This level of response is related to the size of the damaged tissue and can be expressed in a wide dynamic range

"Corresponding author. and decrease rapidly in response to treatment, although not totally reduced in the absence of recovery. The periods of relapse or the presence of secondary complications lead to new elevation of SAA, and are brought about by non-inflammatory processes, nutritional status, exercise, manipulation or other forms of stress, such as transport [5] that should not affect the normal values. On the other hand, endurance horses with SAA levels higher than $1000 \mathrm{ng} / \mathrm{mL}$ may not complete the distance. Thus, high SAA concentration may indicate a poor condition of a horse, resulting in elimination during a competition $[6,7]$. Also, Kent [8] noted that the baseline should remain unchanged with age, sex or genetics of animals. These properties are the most interesting from a clinical perspective of the horse, and are represented by the SAA. Also, the SAA is involved in the defense of the animal in its adaptation or the body's defense against pathogens [9-11]. Thus, the SAA is the protein that responds quickly to stimuli in the horse. Serum concentration of reactant, ie SAA, increases a few hours after the onset of the stimulus, reaches a peak at $24-48 \mathrm{~h}$, and then normalizes $[12,13]$.

\section{Serum Amyloid Type A}

The SAA belongs to the family of apolipoproteins, 
whose molecular weight is estimated at around 9 and 11 $\mathrm{kDa}[14,15]$. The complete sequence of equine SAA was published by Sletten et al. [16]. Three isoforms were identified by their isoelectric point electrophoresis and amino acid sequence [17,18]. SAA3 isoform has been isolated both in hepatocytes during the APR and in various cell types that are checked for extra hepatic synthesis in the digestive tract, airways, mammary gland, synovial tissue and articular cartilage chondrocytes [18-20]. Thus, the protein levels rise substantially in inflammatory arthritis and mastitis [13,18,21,22].

Normal plasma concentrations of SAA in horses range from 0.5 to $20 \mathrm{mg} / \mathrm{L}$ [15,23-27], although in most situations they exceed $7 \mathrm{mg} / \mathrm{L}$ [23]. It is noteworthy that the cytokine responsible for hepatic synthesis of SAA are released from inflamed tissues, regardless of the cause of the injury. For this reason, the SAA is a nonspecific marker of inflammation and therefore cannot be used for etiologic diagnosis. In fact, Hultén et al. [28] identified levels of SAA above $7 \mathrm{mg} / \mathrm{L}$ in both viral and bacterial infections, showing the non-specific nature of this protein. In response to tissue damage after inflammation or infection, these values increase rapidly and reach concentrations ranging between $100-200$ and $1000 \mathrm{mg} / \mathrm{L}[13$, 23]. This type of response develops after $6-8$ hours of the onset of the stimulus, and reaches peak values within $36-48$ hours and then decrease to baseline levels within 1 to 2 weeks in the absence of new stimuli [28]. The plasma clearance of SAA is very fast and is degraded in the liver between 30 minutes and 2 hours after synthesis. Thus, the levels decrease rapidly when the cause of tissue damage ceases [13]. These features make the SAA a suitable marker of real-time inflammatory activity and therefore a good indicator of the current health status of the horse [13,29].

Some studies have suggested that SAA is even more sensitive than classical markers of inflammation, such as white blood cell count and $\mathrm{Fb}[30,31]$, as stated previously. Various factors such as fear, excitement and infections, among others, mainly induce increased cortisol and neutrophilic leukocytosis type levels. Neutrophils have a very limited kinetics and, therefore, are not considered to be markers of the intensity of the trauma [32]. For this reason, to monitor certainly inflammatory or infectious process, the serum profiles of SAA reflect better the course of the inflammation, since they are correlated by the severity of the process. In contrast, fever and changes in the number of leukocytes, are generally considered as markers of inflammation and infection, and are not useful parameters for monitoring post-operatively, due to its non-specificity [29,31].

Until a few years ago and even today, the most widely used APP in equine clinics has been the $\mathrm{Fb}$. Because research in recent years has shown that the APP of choice is the SAA, as it responds more actively to inflammation and/or infection. Among the numerous advantages of the $\mathrm{SAA}$ to $\mathrm{Fb}$ cited, it is quicker responsiveness, the $\mathrm{Fb}$ peak occurs within 7 - 10 days, while the SAA occurs in $24-48 \mathrm{~h}$, and evolves in parallel with the degree of injury and recovery and broader responsiveness. While the $\mathrm{Fb}$ reaches values between $1000-4000$ and $11,500 \mathrm{mg} / \mathrm{L}$, the SAA is significantly lower $(0.5-20 \mathrm{mg} / \mathrm{L})$, the $\mathrm{Fb}$ can be estimated at $1000 \mathrm{mg} / \mathrm{L}$, which allows the degree of injury to be determined. In addition, $\mathrm{Fb}$ does not serve to monitor the effective of the treatment as the response and plasma clearance occur over time. By contrast, the levels of SAA after injury are independent of the values before the onset of the disease [32] and its half-life in blood is very short.

$\mathrm{The} \mathrm{Fb}$ is present in high amounts in healthy horses, and decrease in situations of increased vascular permeability or excessive consumption and coagulation disorders which may mask the inflammatory or infectious process $[13,31,32]$. Finally, the standard method of measurement of $\mathrm{Fb}$ is insensitive to small changes, so it only detects changes above $100 \mathrm{mg} / \mathrm{dL}$ [33]. Furthermore, the levels of SAA rise when the inflammatory process is active, and fall after the cessation of the stimulus. Thus, relapse or exacerbation of inflammation must be accompanied by further increases, indicating the extent of tissue injury. Therefore, repeated measurements provide an objective assessment of the health status, and help to monitor the treatment, the degree of recovery and to decide when the patient is fit to return to perform their normal daily activity $[13,34,35]$.

\section{Factors Related to the Variations of Serum Amyloid Type A Concentration in Horses}

\subsection{Influence of Age and Sex}

Several investigations have examined the effect of age and sex on concentrations of SAA in horses, showing conflicting results. Thus, while gender does not seem to affect basal levels of this protein, age exerts a significant influence on the protein profiles. In neonates, a significant increase occurred at 72 hours after delivery. This increase was related to the combined effect of tissue trauma induced by the passage of the fetus through the birth canal, as well as the release of cytokines from the maternal circulation which reflects on the inflammatory nature of the physical phenomenon of labor [15,36,37]. Also, Stoneham et al. [24] and Paltrinieri et al. [38] related this increase to the ingestion of immunoglobulins from the colostrum. These levels remain elevated until 2 weeks of age $[15,36]$.

In several species, SAA3 isoform has been isolated from colostrum and milk [21,37,39]. Colostral levels of 
this protein are closely related to serum levels in healthy foals at 48 hours after birth, suggesting that the protein can be absorbed intact through the intestine and alter the circulating levels. By contrast, other researchers have shown undetectable levels of this protein in healthy foals during this same time period $[24,33,40]$. These controversial results suggest that fluctuations in the levels of age-dependent SAA are so insignificant that no clinical significance in the horse. In fact, a recent study by Jacobsen et al. [32] showed no variations in this age-associated protein.

However, SAA concentrations have been reported in foals less than 12 months of age and older than 18 months of $21.23 \pm 12.20$ and $14.93 \pm 9.07 \mu \mathrm{g} / \mathrm{mL}$, respectively, according to Satoh et al. [36] and $19.37 \pm$ 9.41 and $21.53 \pm 9.81 \mu \mathrm{g} / \mathrm{mL}$, respectively, according to Nunokawa et al. [15]. In addition, both studies showed significantly lower levels in foals and horses aged 18 months to over 21 years. This evolution experienced by the SAA with age confirmed previous results from research in human [41]. The higher incidence of diseases of diverse origin with advancing age seems to be the source of the increase of this protein in older animals, although not all researchers agree with this theory [33].

\subsection{Reproductive Status}

These proteins are diagnostically useful tools to study several diseases, such as endometritis, in mares [42,43] and bitches [44] and mammary tumor disorders [45], among others. Specifically in the mare, in the authors' knowledge, the scientific literatures is very scarce and fragmentary, and have focused primarily on the peripartum period $[15,36]$, estrous cycle [25] and pregnancy [26, 27]. The studies of Nunokawa et al. [15] and Satoh et al. [36] showed that during the last four months of gestation the levels of SAA remained within the physiological range of reference, ranging from 16.6 to $23.6 \mathrm{mg} / \mathrm{L}$. Serum concentrations were increased 2 days before partum $(23.81 \mu \mathrm{g} / \mathrm{mL})$, reaching levels of $56.74 \pm 136.78 \mathrm{pg} / \mathrm{mL}$ [15] and $101.29 \pm 98.82 \mu \mathrm{g} / \mathrm{mL}$ [36] three days after delivery. This dynamic suggests that birth is an inflammatory event in horse breeding, which could be due to tissue damage induced by the passage of the fetus through the birth canal. However, this increase is modest and the levels of SAA return to normal one month after delivery [15].

Satué and Calvo [25] and Satué et al. [26,27] showed that SAA could not be used to diagnose heat or pregnancy in mares. On the contrary, an increase in SAA in early pregnancy has been related with early embryonic death [46].

Later, Duggan [47] found no significant differences in concentrations of SAA between mares and pregnant women. These same researchers showed significantly higher levels of the SAA3 isoform in colostrum and milk in the serum of pregnant mares in peripartum period. SAA3 levels of colostrum have been associated such features as protection, growth, development and maturation of intestinal cells, immune system and other tissues in the neonate [48-50]. Although it is not precisely known, perhaps the endocrine pattern present in the mare during this period could be responsible for the elevated levels of this protein, since prolactin levels increase rapidly in the last week of gestation [51] and therefore, the production of colostrum, as previously shown in women [52,53].

\subsection{Inflammatory Processes}

As mentioned previously, the concentrations of SAA become very evident in horses with clinical signs of inflammation. Thus, in horses with experimentally induced inflammation, Nunokawa et al. [15] and Satoh et al. [36] showed that concentrations of SAA increased in 2 days after induction, reaching values of 4 to 40 times higher than pretreatment values. Subsequently, these values returned to baseline levels in 10 days to 4 weeks, which coincided with to the disappearance of clinical signs. To monitor the responsiveness of SAA aseptic arthritis in Standardbred horses, serial blood samples were taken by Hultén et al. [30] using the following protocol: before induction $(0 \mathrm{~h})$, at $8,16,24,36$ and 48 hours and then at $3,4,5$ and 15 days post-induction. SAA concentrations increased at 16 hours, reached a peak at 36 - $48 \mathrm{~h} \mathrm{(227}$ times higher than the baseline), and remained elevated for two weeks. In complicated septic arthritis situations, SAA remains elevated both in serum and synovial fluid, so it can be used to monitor treatment effect, and that decreases simultaneously with the action of the treatment $[22,54]$.

Henriksen et al. [55] and Labelle et al. [56] monitored the levels of SAA in the eye and in the local and systemic inflammatory processes accompanying uveitis and corneal ulcers in adult horses and foals with hypopyon. The observed values of SAA in serum and vitreous were significantly higher in foals than in adult animals. Although it was found that this protein does not cross the blood ocular barrier in uveitis and corneal ulcers, the local levels increased significantly in the process of hypopyon. Finally, these same researchers showed that uveitis does not seem to cause an acute phase response.

\subsection{Surgery}

Generically, surgery induces a marked APR, characterized by a biphasic pattern of SAA [23,31,33]. In particular, after castration, SAA levels have been identified above $7 \mathrm{mg} / \mathrm{L}$, with a peak at 2 - 3 days followed by a second rise 4 or 5 days after surgery [23]. This pattern had also previously been shown in mares experimentally 
infected with equine herpesvirus type 1 (EHV-1), although in this case, a second rise occurred later, i.e., at 10 - 12 days from the onset of the process, an expected phenomenon during the inflammatory process [34]. In both cases, the second increase was not accompanied by a worsening of clinical signs and the values returned to the normal reference ranges for 7 - 15 days after surgery [23,32].

In response to surgical stimulus, Satoh et al. [36] and Pollock et al. [33] showed a narrow range for this protein (from 0.0 to $0.1 \mu \mathrm{g} / \mathrm{mL}$ ), which increased rapidly (from 16.1 to $27.29 \mu \mathrm{g} / \mathrm{mL}$ ) compared with other markers of inflammation, such as HP or Fb, suggesting that the SAA is useful in the diagnosis and monitoring of disease with surgical intervention in horses.

In three types of surgery, arthroscopic surgery, correction of the recurrent laryngeal nerve neuropathy, and laparoscopic ovariectomy, Jacobsen et al. [32] affirmed the induction of the APR, and an increase of SAA. The concentrations of IL- 6 were higher in the postoperative period after conventional open surgery, which is a minimally invasive process.

Therefore, this cytokine seems to be a sensitive indicator of the intensity of surgical trauma, since it is the main inducer of the hepatic synthesis of APPs. Jacobsen et al. [32] also described the nature of the surgical trauma that could affect the inflammatory response after surgery. Both the length of the surgical incision, as the degree of tissue disruption and the type of tissue, may influence the magnitude of the inflammatory response. In fact, levels of IL- 6 after abdominal and thoracic surgery are superior to those of a skeletal muscle. Moreover, peritoneal cells produce different types of cytokines, including IL-6, so that laparotomy may result in an increase of these cytokines in the peritoneal fluid, which affect the APR postoperative process [57]. By contrast, the type of anesthetic and the time of exposure to it seem to influence the levels of APPs [32].

The postsurgical inflammatory and infectious complications are also accompanied by significantly higher values of SAA [31], that correlate with the severity of symptoms. Thus, monitoring the SAA allows making quick decisions about the treatment to apply, and thus decrease the discomfort and postoperative complications [22,29].

\subsection{Bacterial and Viral Infections}

Serum levels of SAA were significantly elevated within hours of the establishment of infection, thus behaving as an immediate indicator of the disease. This type of response occurs with infections caused by bacteria $[24,28$, $34,38]$ and viruses [23,28,34]. Specifically, in adult horses with bacterial infections, SAA levels have been reported levels above $2000 \mathrm{mg} / \mathrm{L}$ [13], but there was a more moderate increase associated with viral infections. Thus, the degree of response will help to differentiate the type of microorganisms involved. Hultén et al. [28] showed that although an increase in SAA is not a specific indicator of influenza or other viral infection is it an important diagnostic tool for the control, management and monitoring of viral infections in horses. The SAA response against the influenza virus occurs within 48 hours, and returns to baseline levels after 11 - 22 days, in the absence of complications. Therefore, persistent elevations of SAA beyond the 11 - 22 days could be related to severe infections, infectious complications or tissue damage secondary to another source that goes unnoticed. Thus, the SAA can be used as a prognostic marker in bacterial and viral respiratory diseases on a large scale in herds, indicating the clinical severity and recovery status of the animals [28,34].

Recurrent airway obstruction (RAO) is an inflammatory, obstructive airway disease that becomes clinically evident in middle-aged horses. The disease, also known as heaves, is most prevalent in the northern hemisphere where horses are stabled for large parts of their lives and are fed hay. Attacks of airway obstruction are induced by exposure of susceptible animals to organic dust (typically hay dust). Following dust exposure, there is massive influx of neutrophils into the airways. This is accompanied by bronchospasm and mucus accumulation [58].

Systemic inflammation in horses with heaves is poorly characterized. In a study done by Lavoie-Lamoureux et al. [59], serum haptoglobin concentrations were significantly higher in heaves-affected horses compared with healthy controls. They were also significantly increased by antigen challenge in both controls and horses with heaves. Serum SAA was detected more frequently in heaves-affected horses compared with healthy controls. Thus concluded in heaves, haptoglobin is a marker of both acute and chronic systemic inflammation, while high concentrations of SAA indicate acute inflammation.

\subsection{Neonatal Diseases}

Generically, in newborn foals the manifestations of clinical signs of disease usually are non-specific, so diagnosis is often made with difficulty. For this reason, the accuracy and reliability of the measurement of SAA can provide positive results. In neonates, the SAA rises in the presence of sepsis and infection [24,29,40]. Certain investigations on the evaluation of SAA in foals by noninfectious causes, such as prematurity, failure of passive transfer of immunity, neonatal maladjustment syndrome, isoerythrolysis, meconium impaction, have given conflicting results. In some of these cases the levels of SAA remain within the physiological range of reference [24, 29], while in other situations they are elevated [37,40]. Chronic infections in foals also lead to an increase of 
SAA, although at lower levels than in acute infections [29].

High concentrations of SAA in foals often are indicative of infection. It has also been suggested that values above $100 \mathrm{mg} / \mathrm{L}$ could distinguish infectious from noninfectious causes [24]. In fact, to distinguish these processes, the SAA is more accurate than traditional analytic markers (Fb and leukocyte count) [29]. Neonatal sepsis is a serious problem and a delay in starting treatment can be fatal. Therefore, the SAA measurement can aid in the diagnosis and most appropriate treatment setting in less time [24]. Like in adult horses, localized infections, such as abscesses in umbilical cord of foals, the SAA may remain low or undetectable. This response is related to the location of these abscesses and the removal of the hepatic synthesis [24].

\subsection{Respiratory Processes}

Elevated levels of SAA have been detected in horses infected with influenza [28] and pneumonic processes of unknown etiology $[15,34]$. The SAA in horses with influenza is a more sensitive marker of acute infection detected by nasal swabs. In addition, the SAA is positively correlated with the severity of the clinical disease and decreases or becomes undetectable in horses recovering from viral infection [28]. High concentrations of SAA were detected in foals infected by Rhodococcus equi which decreased after initiating treatment [29]. However, a study conducted in foals younger than 1 month showed no variations in the concentrations of SAA among foals with pneumonia caused by Rhodococcus equi at the time of onset of clinical signs and clinically healthy foals.
Thus, SAA should not be used as a source of reliable diagnosis, but as a tool to assist in the early detection of respiratory tract infections [60].

SAA is also a useful tool to monitor the response to treatment of respiratory tract infections. Secondary bacterial complications or severe influenza processes induce persistent elevations in the levels of SAA [28]. For this reason, the SAA can be used as a marker of the degree of recovery and determine the appropriate convalescence period, avoiding the detrimental effects of a return to daily activity [61].

The responsiveness of SAA has been used to monitor vaccinations against influenza, and tetanus. Generically, vaccination causes a moderate increase of SAA, which begins at 24 hours, persists for 96 hours and decreases in 3 - 4 days $[62,63]$. The A2 influenza virus produces a type of local response which in some cases is systemic and is due to the synthesis of IL-6 and TNF- $\alpha$ [64]. Similarly, inoculation of endotoxins produced by Escherichia coli induces a marked release of IL-1 [65].

It has been hypothesized that the measurement of SAA in horses with respiratory disease could distinguish between infectious and noninfectious type caused by allergic reactions. This justification is based on extrapolating from human situations in which immune-mediated diseases, such as systemic lupus eritrematoso, polymyositis and ulcerative colitis that are associated with a low release of SAA $[66,67]$. At present, it remains to be clarified if allergic or immune-mediated processes develop alterations in the levels of SAA in horses.

Tables 1 and 2 describe the pathological causes commonly associated with elevated levels of SAA in horses.

Table 1. Description of the pathological processes infectious bacterial, septic and aseptic joint inflammation and surgeries that lead to elevated levels of SAA in horses.

\begin{tabular}{|c|c|c|}
\hline Process & Description & References \\
\hline \multirow{3}{*}{ Joint diseases } & Experimentally induced aseptic arthritis & Hultén et al. [23] Hultén and Demmers [29] Jacobsen et al. [18,22] \\
\hline & Naturally induced infectious arthritis & Pepys et al. [34] Jacobsen et al. [24] \\
\hline & IM injection of turpentine oil & Nunokawa et al. [15] \\
\hline \multirow{4}{*}{ Surgery } & Laparotomy & Nunokawa et al. [15] \\
\hline & $\begin{array}{l}\text { Different procedures } \\
\text { (laryngoplasty, ventriculectomy, ovariectomy) }\end{array}$ & $\begin{array}{l}\text { Hultén et al. [17] Pepys et al. [34] } \\
\text { Pollock et al. [33] Jacobsen et al. [32] }\end{array}$ \\
\hline & Castration & Nunokawa et al. [15] Hultén et al. [23] Jacobsen et al. [24] \\
\hline & Arthroscopy & Jacobsen et al. [32] \\
\hline \multirow{6}{*}{$\begin{array}{l}\text { Bacterial } \\
\text { infections }\end{array}$} & Sepsis in foals & $\begin{array}{l}\text { Chavatte et al. [40] Hultén et al. [17] Stoneham et al. } \\
\text { [24] Hultén and Demmers [29] }\end{array}$ \\
\hline & Rhodococcus equi pneumonia & Chavatte et al. [40] Hultén and Demmers [29] \\
\hline & Strangles (Streptococcus equi) & Pepys et al. [34] Hultén et al. [17] \\
\hline & Endometritis by experimental infection of $E$. coli & Chistoffersen et al. [42] \\
\hline & Pyaemia, abscesses, post-operative infections & Jacobsen et al. [32] \\
\hline & Unknown etiology abortion & Nunokawa et al. [15] \\
\hline
\end{tabular}


Table 2. Description of the virus-like disease processes, gastrointestinal, non-infectious, reproductive and metabolic disorders, leading to elevated levels of SAA in horses and describe the processes.

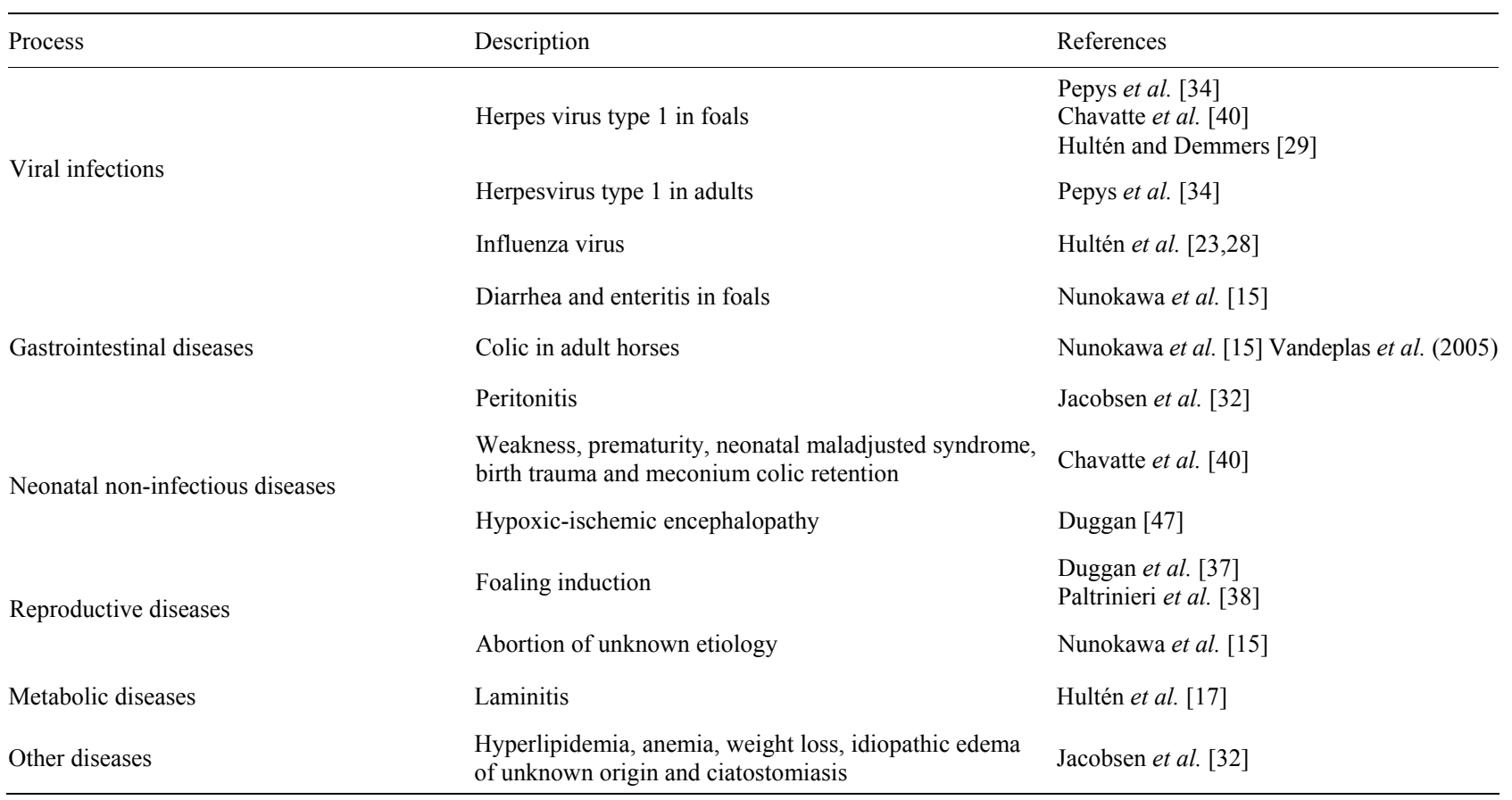

\subsection{Amyloidosis}

Recurrent inflammatory processes with sustained elevations of SAA can lead to reactive amyloidosis. This term covers a variety of diseases involving the deposit of SAA in the muscle fibers of the liver, spleen and kidney. Systemic amyloidosis can have fatal consequences, as verified in horses with repeated immunization for the production of antiserum $[17,68]$.

\section{Conclusion}

The APPs determination of the physiological factor which modifies the APR offers a biological effect mechanism appropriate to assess the health in equine patients. Despite the nonspecific nature of the APR, the estimation of plasma levels of SAA can be useful as a diagnostic aid, helping to differentiate inflammatory from non-inflammatory conditions. Levels of SAA can also be important for management of patients, since they generally reflect the extent and intensity of the inflammatory process and the response to, and need for, therapeutic interventions and prognostic value, that ensures the return to normal healthy condition in the shortest amount of time.

\section{Conflict of Interest Statements}

None of the authors of this paper has a financial or personal relationship with other people or organizations that could inappropriately influence or bias the content of the paper.

\section{REFERENCES}

[1] E. Gruys, M. J. M. Toussaint, W. J. M. Landman, M. Tivapasi, R. Chamanza and L. Van Veen, "Infection, Inflammation and Stress Inhibit Growth. Mechanisms and Non-Specific Assessment of the Processes by Acute Phase Proteins," In: T. Wensing, Ed., Production Diseases in Farm Animals, Wageningen Press, Wageningen, 1999, pp. 72-87.

[2] P. D. Eckersall, "Recent Advances and Future Prospects for the Use of Acute Phase Proteins as Markers of Disease in Animals," Revue de Medicine Veterinary, Vol. 151, No. 7, 2000, pp. 577-578.

[3] J. J. Ceron, P. D. Eckersall and S. Martýnez-Subiela, "Acute Phase Proteins in Dogs and Cats: Current Knowledge and Future Perspectives," Veterinary Clinical Pathology, Vol. 34, No. 2, 2005, pp. 85-99. doi:10.1111/j.1939-165X.2005.tb00019.x

[4] M. V. Crisman, W. K. Scarratt and K. L. Zimmerman, "Blood Proteins and Inflamationin the Horse," Veterinary Clinics of North America: Equine Practice, Vol. 24, No. 2, 2008, pp. 285-297. doi:10.1016/j.cveq.2008.03.004

[5] S. Casella, F. Fazio, C. Giannetto, E. Giudice and G. Piccione, "Influence of Transportation on Serum Concentrations of Acute Phase Proteins in Horse," Research Veterinary Science, Vol. 93, No. 2, 2012, pp. 914-917. doi:10.1016/j.rvsc.2012.01.004

[6] A. Cywinska, R. Gorecka, E. Szarska, L. Witkowki, P. Dziekan and A. Scholienberger, "Serum Amyloid A Level as a Potential Indicator of the Status of Endurance Horses," Equine Veterinary Journal, Vol. 42, No. S38, 2010, pp. 23-27. doi:10.1111/j.2042-3306.2010.00280.x

[7] A. Cywińska, E. Szarska, R. Górecka, L. Witkowski, M. 
Hecold, A. Bereznowski, A. Schollenberger and A. Winnicka, "Acute Phase Protein Concentrations after Limited Distance and Long Distance Endurance Rides in Horses," Research Veterinary Science, Vol. 93, No. 3, 2012, pp. 1402-1406. doi:10.1016/j.rvsc.2012.02.008

[8] J. Kent, "Acute Phase Proteins: Their Use in Veterinary Diagnosis," British Veterinary Journal, Vol. 148, No. 4, 1992, pp. 279-282. doi:10.1016/0007-1935(92)90081-B

[9] D. Thompson, A. Mildford-Ward and J. Whicher, "The Value of Acute Phase Measurements in Clinical Practice," Annals of Clinical Biochemistry, Vol. 29, No. 2, 1992, pp. 123-131.

[10] I. Kushner and A. Mackiewicz, "The Acute Phase Response: An Overview," In: A. Mackiewicz, I. Kushner, H. Baumann, Eds., Acute Phase Proteins Molecular Biology, Biochemistry and Clinical Applications, CRC Press, Boca Ratón, 1993, pp. 3-19.

[11] A. Hillström, H. Tvedten and I. Liliehöök, "Evaluation of an In-Clinic Serum Amyloid A (SAA) Assay and Assessment of the Effects of Storage on SAA Samples," Acta Veterinaria Scandinavica, Vol. 2, No. 1, 2010, pp. 52-58.

[12] C. Gabay and I. Kushner, "Acute Phase Proteins and Other Systemic Responses to Inflammation," New England Journal of Medicine, Vol. 340, 1999, pp. 448-454. doi:10.1056/NEJM199902113400607

[13] S. Jacobsen and P. H. Andersen, "The Acute Phase Protein Serum Amyloid A (SAA) as a Marker of Inflammation in Horses," Scandinavian Journal of Immunology Vol. 19, No. 1, 2007, pp. 38-46.

[14] A. Husebekk, G. Husby, K. Sletten, G. Marhaug and K. Nordstoga, "Characterization of Amyloid Protein AA and Its Serum Precursor SAA in the Horse," Scandinavian Journal of Immunology, Vol. 23, No. 6, 1986, pp. 703709. doi:10.1111/j.1365-3083.1986.tb02007.x

[15] Y. Nunokawa, T. Fujinaga, T. Taira, M. Okumura, K. Yamashita, N. Tsunoda and M. Hagio, "Evaluation of Serum Amyloid A Protein as an Acute-Phase Reactive Protein in Horses," Journal of Veterinary Medical Science, Vol. 55, No. 6, 1993, pp. 1011-1016. doi:10.1292/jvms.55.1011

[16] K. Sletten, A. Husebekk and G. Husby, "The Primary Structure of Equine Serum Amyloid A (SAA) Protein," Scandinavian Journal of Immunology, Vol. 30, No. 1, 1989, pp. 117-122. doi:10.1111/j.1365-3083.1989.tb01195.x

[17] C. Hultén, K. Sletten, C. F. Bruun and G. Marhaug, "The Acute Phase Serum Amyloid A Protein (SAA) in the Horse: Isolation and Characterization of Three Isoforms," Veterinary Immunology Immunopathology, Vol. 57, No. 3-4, 1999, pp. 215-227. doi:10.1016/S0165-2427(97)00021-4

[18] S. Jacobsen, Th. A. Niewold, M. H. Thomsen, S. Nanni, C. Lindegaard, E. Olsen and P. H. Andersen, "Serum Amyloid A Isoforms in Serum and Synovial Fluid in Horses with Lipopolysaccharide-Induced Arthritis," Veterinary Immunology Immunopathology, Vol. 112, No. 3-4, 2006 , pp. 321-322. doi:10.1016/j.vetimm.2005.10.014

[19] L. C. Berg, S. Jacobsen and P. D. Thomsen, "Local Production of Serum Amyloid A in Equine Articular Carti- lage and Cultured Chondrocytes," International Journal of Experimental Pathology, Vol. 88, No. 4, 2007, pp. 5859.

[20] L. C. Berg, P. D. Thomsen, P. H. Andersen, H. E. Jensen and S. Jacobsen, "Serum Amyloid A Is Expressed in Histologically Normal Tissues from Horses and Cattle," Veterinary Immunology and Immunopathology, Vol. 144, No. 1-2, 2011, pp. 155-159. doi:10.1016/j.vetimm.2011.06.037

[21] T. L. McDonald, M. A. Larson, D. R. Mack and A. Weber, "Elevated Extrahepatic Expression and Secretion of Mammary-Associated Serum Amyloid A 3 (M-SAA3) into Colostrum," Veterinary Immunology Immunopathology, Vol. 83, No. 3-4, 2001, pp. 203-211. doi:10.1016/S0165-2427(01)00380-4

[22] S. Jacobsen, M. H. Thomsen and S. Nanni, "Concentrations of Serum Amyloid A in Serum and Synovial Fluid from Healthy Horses and Horses with Joint Disease," American Journal of Veterinary Research, Vol. 67, No. 10, 2006, pp. 1738-1742. doi:10.2460/ajvr.67.10.1738

[23] C. Hultén, R. M. Tulamo, M. M. Suominem, K. Burwall, G. Marhaug and M. Forsberg, "A Non-Competitive Chemiluminescence Enzyme Immunoassay for the Equine Acute Phase Protein Serum Amyloid A (SAA)-A Clinically Useful Inflammatory Marker in the Horse," Veterinary Immunology Immunopathology, Vol. 68, No. 2-4, 1999, pp. 267-281. doi:10.1016/S0165-2427(99)00027-6

[24] S. J. Stoneham, L. Palmer, R. Cash and P. D. Rossdale, "Measurement of Serum Amyloid A in the Neonatal Foal Using a Latex Agglutination Immunoturbidimetic Assay: Determination of the Normal Range, Variation with Age and Response to Disease," Equine Veterinary Journal, Vol. 33, 2001, pp. 559-603.

[25] K. Satué and A. Calvo, "Normal Values of Serum Amyloid A, Haptoglobin and C-Reactive Protein in Spanish Purebred Mares during Estrous Cycle," Proceeding of the 16th Italian Association of Equine Veterinarians Congress, Carrara, 29-31 January 2010, p. 263.

[26] K. Satué, A. Calvo and P. Montesinos, "Normal Values of Serum Amyloid A, Haptoglobin and C-Reactive Protein in Spanish Purebred Mares during Pregnancy," Proceeding of the 12th International Congress of European College of Veterinary Internal Medicine, Dublin, 1-3 September 2010, p. 549.

[27] K. Satué, A. Calvo and J. J. Cerón, "Proteínas de Fase Aguda: Pueden ser Utilizadas Como Fuente de Diagnóstico de Gestación en la Yegua Pura Raza Española?" Proceeding of the 10th International Congress of Medicine and Surgery Equine, Sevilla, 27-28 November 2010, pp. 141-144.

[28] C. Hultén, B. Sandgren, E. Skiöldebrand, B. Kligeborn, G. Marhaug and M. Forsberg, "The Acute Phase Protein Serum Amyloid A (SAA) as an Inflammatory Marker in Equine Influenza Virus Infection," Acta Veterinaria Scandinavica, Vol. 40, No. 4, 1999, pp. 323-333.

[29] C. Hultén and S. Demmers, "Serum Amyloid A (SAA) as an Aid in the Management of Infectious Disease in the Foal: Comparison with Total Leucocyte Count, Neutrophil Count and Fibrinogen," Equine Veterinary Journal, 
Vol. 34, No. 7, 2002, pp. 693-698. doi: $10.2746 / 042516402776250360$

[30] C. Hultén, U. Grönlund, J. Hirvonen, R. M. Tulamo, M. M. Suominem, G. Marhaug and M. Forsberg, "Dynamics in the Serum of the Inflammatory Markers Serum Amyloid A (SAA), Haptoglobin, Fibrinogen and $\alpha 2$-Globulins during Induced Non-Infectious Arthritis in the Horse," Equine Veterinary Journal, Vol. 34, No. 7, 2002, pp. 669704.

[31] S. Jacobsen, J. C. Jensen, S. Frei, A. L. Jensen and M. B. Thoefner, "Use of Serum Amyloid A and Other Acute Phase Reactants to Monitor the Inflammatory Response after Castration in Horses: A Field Study," Equine Veterinary Journal, Vol. 37, No. 6, 2005, pp. 552-556. doi:10.2746/042516405775314853

[32] S. Jacobsen, J. V. Nielsen, M. Kjelgaard-Hansen, T. Toelboell and J. Fjeldborg, "Acute Phase Response to Surgery of Varying Intensity in Horses: A Preliminary Study," Veterinary Surgery, Vol. 38, No. 6, 2009, pp. 762-769. doi:10.1111/j.1532-950X.2009.00564.X

[33] P. J. Pollock, M. Prendergast, J. Schumacher and C. R. Bellenger, "Effects of Surgery on the Acute Response in Clinically Normal and Diseased Horses," Veterinary Record, Vol. 156, No. 17, 2005, pp. 538-542.

[34] M. B. Pepys, M. L. Baltz and G. A. Tennent, "Serum Amyloid A protein (SAA) in Horses: Objective Measurement of the Acute Phase Response," Equine Veterinary Journal, Vol. 21, No. 2, 1989, pp. 106-109. doi:10.1111/j.2042-3306.1989.tb02108.x

[35] M. Christensen, S. Jacobsen, T. Ichiyanagi and M. Kjelgaard-Hansen, "Evaluation of an Automated Assay Base Don Monoclonal Anti-Human Serum Amyloid A (SAA) Antibodies for Measurement of Canine, Feline and Equine SAA," Veterinary Journal, Vol. 194, No. 3, 2012, pp. 332-337. doi:10.1016/j.tvj1.2012.05.007

[36] M. Satoh, T. Fujinaga, M. Okumura and M. Hagio, "Sándwich Enzyme-Linked Immunosorbent Assay for Quantitative Measurement of Serum Amyloid A Protein in Horses," American Journal of Veterinary Research, Vol. 56, Vol. 10, 1995, pp. 1286-1291.

[37] V. Duggan, G. R. Holyoak, C. G. Mac Allister and A. W. Confer, "Influence of Induction of Parturition on the Neonatal Acute Phase Response in Foals," Theriogenology, Vol. 67, No. 2, 2007, pp. 372-381. doi:10.1016/j.theriogenology.2006.06.015

[38] S. Paltrinieri, "The Feline Acute Phase Reaction," Veterinary Journal, Vol. 177, No. 1, 2008, pp. 26-35. doi:10.1016/j.tvj1.2007.06.005

[39] E. Harada, Y. Araki, E. Furumura, T. Takeuchi, K. Sitizyo, T. Yajima and T. Kuwata, "Characteristic Transfer of Colostrum-Derived Biologically Active Substances into Cerebrospinal Fluid via Blood in Natural Suckling Neonatal Pigs," Journal of Veterinary Medicine A Physiology, Pathology, Clinical Medicine, Vol. 49, No. 7, 2002, pp. 358-364. doi:10.1046/j.1439-0442.2002.00457.x

[40] P. M. Chavatte, M. B. Pepys, B. Roberts, J. C. Ousey, A. J. McGladdery and P. D. Rossdale, "Measurement of Serum Amyloid A protein (SAA) as an Aid to Differential Diagnosis of Infection in Newborn Foals," In: W. Plow- right, P. D. Rossdale, J. F. Wade and J. F. Eds., Equine Infectious Diseases 6, Proceedings of the 6th International Conference, R\&W Publications, Newmarket, 1992, pp. 33-38.

[41] C. J. Rosenthal and E. C. Franklin, "Variation with Age and Disease of an Amyloid A Protein-Related Serum Component," Journal of Clinical Investigation, Vol. 55, No. 4, 1975, pp. 746-753. doi:10.1172/JCI107985

[42] M. Chistoffersen, C. Baagore, S. Jacobsen, A. M. Bojesen, M. R. Petersen and H. Lehn-Jensen, "Evaluation of the Systemic Acute Phase Response and Endometrial Gene Expression of Serum Amyloid A and Pro- and Anti-Inflammatory Cytokines in Mares with Experimentally Induced Endometritis," Veterinary Immunology and Immunopathology, Vol. 138, No. 1-2, 2010, pp. 95-105. doi:10.1016/j.vetimm.2010.07.011

[43] M. Christoffersen, E. Woodward, A. M. Bojesen, S. Jacobsen, M. R. Petersen, M. H. Troedsson and H. LehnJensen, "Inflammatory Responses to Induced Infectious Endometritis in Mares Resistant or Susceptible to Persistent Endometritis," BMC Veterinary Research, Vol. 29, No. 8, 2012, p. 41. doi:10.1186/1746-6148-8-41

[44] R. Dabrowski, K. Kostro, U. Lisiecka, M. Szczubiał and L. Krakowski, "Usefulness of C-Reactive Protein, Serum Amyloid A Component, and Haptoglobin Determinations in Bitches with Pyometra for Monitoring Early PostOvariohysterectomy Complications," Theriogenology, Vol. 72, No. 4, 2009, pp. 471-476.

doi:10.1016/j.theriogenology.2009.03.017

[45] F. Tecles, M. Caldín, A. Zanella, F. Membiela, A. Tvarijonaviciute, S. Martínez Subiela and J. J. Cerón, "Serum Acute Phase Protein Concentrations in Female Dogs with Mammary Tumors," Journal of Veterinary Diagnostic Investigation, Vol. 21, No. 2, 2009, pp. 214-219. doi:10.1177/104063870902100206

[46] L. Krakowski, C. H. Krawcyk, K. Kostro, T. Stefaniak, F. Novotry and J. Obara, "Serum Levels of Acute Phase Proteins: SAA, Hp and Progesterone (P4) in Mares with Early Embryonic Death," Reproduction in Domestic Animals, Vol. 46, No. 4, 2011, pp. 624-629. doi:10.1111/j.1439-0531.2010.01715.x

[47] V. Duggan, "Serum Amyloid A in the Neonatal Foal: The Significance of Peri-Parturient Events," Veterinary Journal, Vol. 176, No. 3, 2008, pp. 267-269. doi:10.1016/j.tvj1.2007.08.029

[48] M. A. Larson, S. H. Wei, A. Weber, A. T. Weber and T. L. McDonald, "Induction of Human Mammary-Associated Serum Amyloid A3 Expression by Prolactin or Lipopolysaccharide," Biochemical and Biophysical Research Communications, Vol. 301, No. 4, 2003, pp. 1030-1037. doi:10.1016/S0006-291X(03)00045-7

[49] D. R. Mack, T. L. McDonald, M. A. Larson, S. Wei and A. Weber, "The Conserved TFLK Motif of MammaryAssociated Serum Amyloid A3 Is Responsible for UpRegulation of Intestinal MUC3 Mucin Expression in Vitro," Pediatric Research, Vol. 53, 2003, pp. 137-142. doi:10.1203/00006450-200301000-00023

[50] A. J. Molenaar, D. P. Harris, G. H. Rajan, M. L. Pearson, M. R. Callaghan, L. Sommer, V. C. Farr, K. E. Oden, M. 
C. Miles, R. S. Petrova, L. L. Good, K. Singh, R. D. McLaren, C. G. Prosser, K. S. Kim, R. J. Wieliczko, M. H. Dines, K. M. Johannessen, M. R. Grigor, S. R. Davis and K. Stelwagen, "The Acute-Phase Protein Serum Amyloid A3 Is Expressed in the Bovine Mammary Gland and Plays a Role in Host Defense," Biomarkers, Vol. 14, No. 1, 2009, pp. 26-37. doi:10.1080/13547500902730714

[51] K. Baintner and J. Csapó, "Lack of Acid-Resistant Trypsin Inhibitor in Mare's Colostrum: Short Communication," Acta Veterinaria Hungarica, Vol. 44, No. 1, 1996, pp. 95-97.

[52] G. P. Sacks, K. Studena, I. L. Sargent and W. G. Redman, "Normal Pregnancy and Pre-Clampsia Both Produce Inflammatory Changes in Peripheral Blood Leukocytes Akin to Those of Sepsis," American Journal of Obstetrics \& Gynecology, Vol. 179, No. 1, 1988, pp. 80-86. doi:10.1016/S0002-9378(98)70254-6

[53] M. D. Savvidou, C. C. Lees, M. Parra, A. D. Hingorani and K. H. Nicolaides, "Levels of C-Reactive Protein in Pregnant Women Who Subsequently Develop Pre-Clampsia," BJOG, Vol. 109, No. 3, 2002, pp. 297-301. doi:10.1111/j.1471-0528.2002.01130.x

[54] A. F. Sanchez Teran, L. M. Rubio-Martinez, N. F. Villarino and M. G. Sanz, "Effects of Repeated Intra-Articular Administration of Amikacin on Serum Amyloid A, Total Protein and Nucleated Cell Count in Sinovial Fluid from Healthy Horses," Equine Veterinary Journal, Vol. 44, No. S43, 2012, pp. 12-16. doi:10.1111/j.2042-3306.2012.00637.x

[55] M. Henriksen, S. Jacobsen and P. H. Andersen, "Serum Amyloid A (SAA) in Equine Serum and Vitreous," Veterinary Ophthalmology, Vol. 12, No. 1, 2009, pp. 6-7.

[56] A. L. Labelle, R. E. Hamor, A. L. Macneill, K. M. Lascola, C. B. Breaux and E. L. Tolar, "Effects of Ophthalmic Disease on Concentrations of Plasma Fibrinogen and Serum Amyloid A in the Horse," Equine Veterinary Journal, Vol. 43, No. 4, 2011, pp. 460-465. doi:10.1111/j.2042-3306.2010.00305.X

[57] K. Tsukada, S. Takenoshita and Y. Nagamachi, "Peritoneal Interleukin-6, Interleukin-8, and Granulocyte Elastase Activity after Elective Abdominal Surgery," APMIS, Vol. 102, No. 7-12, 1994, pp. 837-840. doi:10.1111/j.1699-0463.1994.tb05242.x

[58] N. E. Robinson, "Recurrent Airway Obstruction (Heaves)," In: P. Lekeux, Ed., Equine Respiratory Diseases, International Veterinary Information Service, Ithaca, New York, 2001.
[59] A. Lavoie-Lamoureux, M. Leclere, K. Lemos, B. Wagner and J. P. Lavoie, "Markers of Systemic Inflammation in Horses with Heaves," Journal Veterinary Internal Medicine, Vol. 26, No. 6, 2012, pp. 1419-1426. doi:10.1111/j.1939-1676.2012.00993.x

[60] N. D. Cohen, M. K. Chaffin, M. L. Vandenplas, R. F. Edwards, M. Nevill, J. N. Moore and R. J. Martens, "Study of Serum Amyloid A Concentrations as a Means of Achieving Early Diagnosis of Rhodococcus equi Pneumonia," Equine Veterinary Journal, Vol. 37, No. 3, 2005, pp. 212216. doi: $10.2746 / 0425164054530704$

[61] H. H. Petersen, J. P. Nielsen, C. Helweg and P. M. Heegård, "Application of Acute Phase Protein Measurements in Veterinary Clinical Chemistry," Veterinary Research, Vol. 35, No. 2, 2004, pp. 163-187. doi: $10.1051 /$ vetres:2004002

[62] S. A. Andersen, H. H. Petersen, A. K. Ersboll, J. FalkRonne, A. L. Jensen and S. Jacobsen, "Equine Serum Amyloid A Response Following Vaccination against Influenza and Tetanus," Proceeding of International Colloquium on Acute Phase Proteins, Dublin, 14-15 March 2005, p. 36

[63] S. A. Andersen, H. H. Petersen, A. K. Ersboll, J. FalkRonne, A. L. Jensen and S. Jacobsen, "Vaccination Elicits a Prominent Acute Phase Response in Horses," Veterinary Journal, Vol. 121, No. 2, 2012, pp. 199-202. doi:10.1016/j.tvj1.2011.01.019

[64] E. Wattrang, D. M. Jesset, P. Yates, L. Fuxler and D. Hannant, "Experimental Infection of Ponies with Equine Influenza A2 (H3N8) Virus Strains of Different Pathogenicity Elicits Varying Interferon and Interlukin-6 Responses," Viral Immunology, Vol. 16, No. 1, 2003, pp. 57-67. doi:10.1089/088282403763635456

[65] J. Danek, "Level of Interlukin- $\beta$ and Clinical Signs after Endotoxin Injection in Stallions," Bulletin of the Veterinary Institute Pulawy, Vol. 46, 2002, pp. 179-185.

[66] M. B. Pepys, "C-Reactive Protein Fifty Years on," Lancet, Vol. 317, No. 8221, 1981, pp. 653-857. doi:10.1016/S0140-6736(81)91565-8

[67] J. T. Whicher and P. Dieppe, "Acute Phase Proteins," Journal of Allergy and Clinical Immunology, Vol. 5, 1985, pp. 425-446.

[68] G. Husby, "Equine Amyloidosis," Equine Veterinary Journal, Vol. 20, No. 4, 1988, pp. 235-238. doi:10.1111/j.2042-3306.1988.tb01510.x 